\title{
Theory in Action: \\ Reclaiming the Political Thought of Christopher Caudwell
}

\author{
Amy Buzby ${ }^{1}$
}

This article reclaims the praxis of Christopher Caudwell, a largely forgotten British Marxist who died in the Spanish Civil War. The author argues that Caudwell's work continues to offer important challenges and insights to contemporary Marxist theory and activism. The focus herein is placed on Caudwell's rich conception of freedom, which immediately binds thought to action and demands that Marxists refuse to live by the norms of bankrupt bourgeois hegemony. Caudwell, in other words, points towards means for precisely the type of reflexive and committed action that Marxism needs today. Just as importantly, he insists that we use them. [Article copies available for a fee from The Transformative Studies Institute. E-mail address: journal@transformativestudies.org

http://www.transformativestudies.org (C)2013 by The Transformative Studies Institute. All rights reserved.]

KEYWORDS: Marxism, Praxis, Dialectical Materialism, Democracy, Caudwell.

Much of Marxism's power comes from the dialectical search for the aspects of the present that point towards the possibilities of the future: this mode of inquiry (and the forms of praxis it produces), despite its revolutionary aims, requires ongoing attention to the past. Marx's scientific socialism, in other words, is a project made possible and meaningful by the unfolding of history. Given Marxism's dialectical

\footnotetext{
${ }^{1}$ Amy Buzby, Ph.D., is an assistant professor of political science at Arkansas State University. She received her doctorate in political science from Rutgers University - New Brunswick in 2011. She is also a former academic fellow of the Psychoanalytic Center of Philadelphia. Her published work includes an edited volume, Communicative Action: The Logos Interviews. Her research interests include critical theory, psychoanalysis, Marxism and animal rights. Address correspondence to: Amy Buzby, Arkansas State University, 2105 Aggie Road, Jonesboro, AR 72401; e-mail: abuzby@astate.edu.
} 